\title{
PACIENTŲ, PATYRUSIŲ SPONTANINE INTRASMEGENINE KRAUJOSRUVĄ, PERIFERINIO KRAUJO LEUKOCITŲ SĄSAJA SU LIGOS BAIGTIMI
}

\author{
Benas Kakta ${ }^{1}$, Lolita Grygalytè ${ }^{1}$, Tomas Tamošuitis ${ }^{2}$, Neringa Balčiūnienè ${ }^{2}$ \\ ${ }^{1}$ Lietuvos sveikatos moksly universiteto Medicinos akademijos Medicinos fakultetas, \\ ${ }^{2}$ Lietuvos sveikatos moksly universiteto Medicinos akademijos Neurochirurgijos klinika, \\ Neurochirurgijos intensyvios terapijos skyrius
}

Raktažodžiai: intrasmegeninė kraujosruva, leukocitozė, neutrofilai, neutrofilų ir limfocitų santykis.

\section{Santrauka}

Tikslas. İvertinti pacientų, patyrusių spontaninę intrasmegeninę kraujosruvą (ISK), periferinio kraujo leukocitų ir jų populiacijų ryšį su ligos baigtimi.

Metodika. Atlikta retrospektyvinė 74 pacientų, gydytų Lietuvos sveikatos mokslų universiteto ligoninès Kauno klinikų (LSMUL KK) Neurochirurgijos intensyvios terapijos skyriuje (NITS) 2018-2019 m. dèl patirtos spontaninès ISK, ligos istorijų analizè. Analizuoti tiriamujų demografiniai rodikliai, periferinio kraujo leukocitai ir jų populiacijos, Glasgow komų skalès (GKS) įverčiai, ISK tūriai bei ligos baigtis.

Rezultatai. Mirusių pacientų leukocitų, neutrofilų skaičius bei neutrofilų ir limfocitų santykis (NLS) buvo didesni, nei išgyvenusių $(\mathrm{p}<0,05)$. Atlikus tiesinę regresiją nustatyta, kad didesnis NLS siejasi su didesniu ISK tūriu ( $\beta=1,887$, koreg. $\left.\mathrm{R}^{2}=0,051, \mathrm{p}=0,03\right)$, tuo tarpu su mažesniu GKS įverčiu susijęs didesnis bendras leukocitu skaičius $\left(\beta=-0,298\right.$, koreg. $R^{2}=0,062$, $p=0,018)$ ir absoliutus neutrofilu skaičius $(\beta=-0,308$, koreg. $\left.\mathrm{R}^{2}=0,064, \mathrm{p}=0,017\right)$. Atlikus logistinę regresiją nustatyta, kad su didesne mirties tikimybe susijęs didesnis bendras leukocitu ( $\mathrm{GS}=1,156, \mathrm{p}=0,031)$, absoliutus neutrofilų skaičius ( $G S=1,167, p=0,024)$ ir NLS ( $\mathrm{GS}=1,091, \mathrm{p}=0,028)$.

Išvados. Didesnis periferinio kraujo leukocitų skaičius susijęs su mažesniu GKS įverčiu ir didesne mirties tikimybe. Didesnis neutrofilų skaičius siejasi su mažesniu GKS ịverčiu ir didesne mirties tikimybe, o didesnis NLS susijęs su didesniu ISK tūriu ir didesne mirties tikimybe.

\section{Ivadas}

Spontaninė intrasmegeninè kraujosruva - tai su trauma nesusijęs kraujavimas ị smegenų parenchimą, kuris sudaro apie 10-20 proc. insulto atvejų ir yra siejamas su dideliu komplikacijų skaičiumi, mirštamumu ir bloga baigtimi [1,2]. Literatūros duomenimis, mirštamumas siekia iki 55 proc. visų atvejų ir puse šių mirčių įvyksta per pirmąsias 48 val. nuo simptomų pasireiškimo [2,3]. Kraujosruvos tūrio didèjimas, kraujavimas ị skilvelius kartu su hidrocefalija, smegenų edema ir hiperglikemija yra pagrindinès spontaninès intrasmegeninès kraujosruvos komplikacijos, lemiančios didesni ankstyvą mirštamumą ir neigiamą ligos dinamiką $[2,4]$. Nepaisant diagnostikos ir gydymo tobulejjimo, mirštamumas patyrusių spontaninę intrasmegeninę kraujosruvą išlieka didelis, tad ši patologija plačiai tyrinejjama, bandant geriau suvokti jos patofiziologiją ir veiksnius, kurie turi ịtakos pacientų ligos baigčiai.

Spontaninè intrasmegeninè kraujosruva sukelia pirminius ir antrinius smegenų pažeidimus. Pirminiai pažeidimai ìvyksta dèl kraujosruvos plètimosi ir intrakranijinio slègio padidejjimo. Antrinio pažeidimo patofiziologijoje labai svarbus veiksnys yra uždegiminio proceso vystymasis $[5,6]$. Ivykus spontaninei ISK, pažeidimo vietą infiltruoja kraujo komponentai - eritrocitai, leukocitai, makrofagai, plazmos proteinai. Šios ląstelès skatina uždegiminių mediatorių išlaisvinimą, proteazių, mikroglijos ląstelių ir astrocitų aktyvaciją, kurie sukelia antrinę pažaidą [6]. Atlikti tyrimai parodè, kad periferinio kraujo leukocitų ir jų atskirų populiacijų (ypač neutrofilų ir monocitų) skaičiaus didèjimas gali būti siejamas su kraujosruvos tūrio didèjimu, padidejusiu mirštamumu ir blogesnèmis baigtimis $[5,7]$. Šie duomenys galètų padèti atverti naujas terapijos galimybes pacientams, patyrusiems ISK.

Tyrimo tikslas - įvertinti pacientų, patyrusių spontaninę intrasmegeninę kraujosruvą, periferinių kraujo ląstelių - leu- 
kocitų ir jų populiacijų (neutrofilų, limfocitų, monocitų) skaičiaus ryši su ligos baigtimi.

\section{Tyrimo objektas ir metodai}

Atliktas retrospektyvinis tyrimas. Analizuoti Lietuvos sveikatos mokslų universiteto ligoninès Kauno klinikų Neurochirurgijos intensyvios terapijos skyriuje (NITS) dèl spontaninès intrasmegeninès kraujosruvos $2018 \mathrm{~m}$. sausio - $2019 \mathrm{~m}$. gruodžio mèn. gydytų pacientų ligos istorijų duomenys ir kompiuterinès tomografijos (KT) vaizdai. Tyrimui atlikti gautas Bioetikos centro leidimas Nr. BEC-MF-118.

I tyrimą iš viso įtraukti 74 pacientai, imties sudarymo schema pavaizduota 1 paveiksle.

Itraukimo į tyrimą kriterijai: 1) pacientai, stacionarizuoti ị LSMUL KK NITS dèl pirminès spontaninès intrasmegeninès kraujosruvos, išskyrus izoliuotą intraskilvelinę kraujosruvą; 2) amžius $>18$ metų; 3) galima analizuoti pacientų kompiuterinės tomografijos vaizdus.

Analizuoti pacientų demografiniai duomenys, bendrų kraujo tyrimų (bendras leukocitų skaičius, absoliutūs neutrofilų, limfocitų ir monocitų ląstelių skaičiai), atliktų tik pacientui patekus ị gydymo įstaigą, rezultatai, Glasgow komos skalès (GKS) ịver-

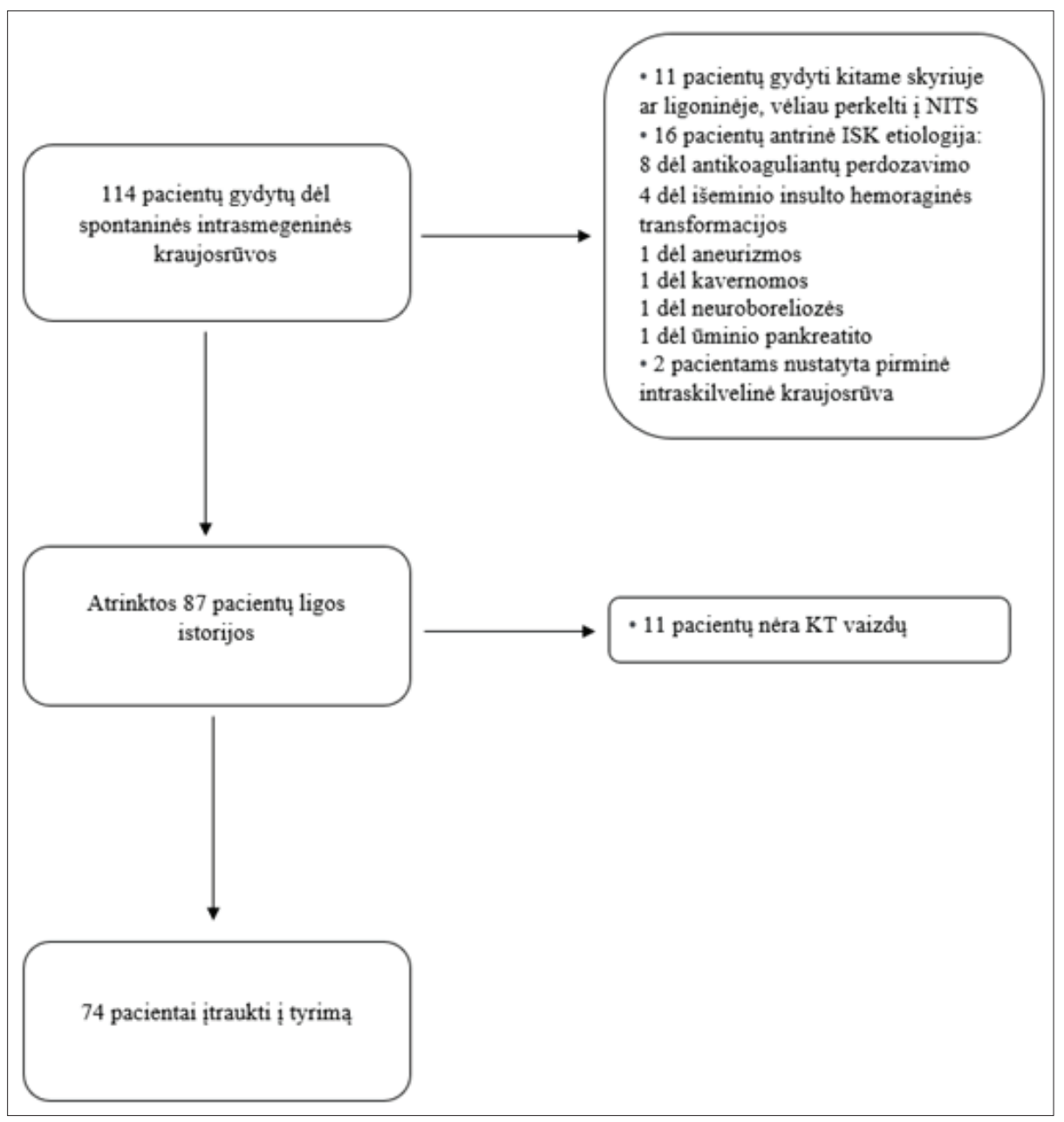

1 pav. Imties sudarymo schema čiai SPS ir stacionarizavus i NITS, kompiuterinès tomografijos vaizdai (kraujosruvos lokalizacija ir tūris). ISK tūris mililitrais apskaičiuotas pagal $\mathrm{ABC} / 2$ metodiką, kur matmuo A yra didžiausias hematomos skersmuo, matmuo B - skersmuo, statmenas didžiausiam skersmeniui, o matmuo $\mathrm{C}$ yra KT pjūvių skaičius, kuriuose matoma hematoma, padalintas iš pjūvio storio [8].

Gautieji duomenys ir tyrimo rezultatai apdoroti SPSS Statistics 25.0 programine įranga. Kiekybinių požymių reikšmès grupèse buvo lyginamos taikant Mann-Whitney kriterijų. Vertinant nepriklausomų kintamujų itaką, priklausomų kintamujjų kitimui atlikta tiesinè regresijos analizè. Siekiant nustatyti nepriklausomų kintamujų įtaką priklausomam kintamajam, atlikta dvinarè logistinè regresija. Rezultatai aprašyti pateikiant vidurkius ir standartinius nuokrypius arba medianas ir pirmaji bei trečiajij kvartilius (Q1-Q3). Rezultatai laikyti statistiškai reikšmingais, kai $\mathrm{p}<0,05$.

\section{Rezultatai}

Išanalizuotos 74 pacientų ligos istorijos. Iš jų $49(66,2 \%)$ vyrai ir $25(33,8 \%)$ moterys. Vidutinis tiriamuju amžius $66,31 \pm 12,45$ metur. Detalesni tiriamosios imties duomenys pateikiami 1 lentelejje.

Išanalizavus pradinių kraujo tyrimų periferinio kraujo ląstelių skaičiaus (leukocitų, neutrofilų, limfocitų, monocitų, neutrofilu ir limfocitu santykio (NLS), limfocitų ir monocitų santykio (LMS)) vidurkius ir palyginus juos tarp mirusių ir išgyvenusių pacientų, nusta- 
tyta, kad mirusių pacientu periferinio kraujo tyrime buvo stebimi statistiškai reikšmingai didesni leukocitų kiekiai (vidurkis $11,48( \pm 4,61), \mathrm{p}=0,024)$, neutrofilu kiekiai (vidurkis $9,19( \pm 4,41), \mathrm{p}=0,019)$ ir NLS (vidurkis $10,02( \pm 7,47)$, $\mathrm{p}=0,044)$. Kitų ląstelių skaičius ar santykiai tarp grupių reikšmingai nesiskyrè (2 lentelè).

1 lentelè. Tiriamosios imties charakteristikos.

Kintamieji nurodyti kaip skaičius ir procentine imties dalis, kuria sudaro kintamasis - n(\%), arba kaip vidurkis su standartiniu nuokrypiu - V( $\pm S N)$. ISK - intrasmegenine kraujosruva. IVK - intraventrikulinè kraujosruva. GKS - Glasgow komu skalè. SPS - skubios pagalbos skyrius. NITS - neurochirurgijos intensyvios terapijos skyrius.

\begin{tabular}{|l|l|}
\hline \multicolumn{2}{|c|}{ Imties charakteristikos (n=74) } \\
\hline Amžius & $66,31( \pm 12,45)$ \\
\hline Vyrai & $49(66,2)$ \\
Moterys & $25(33,8)$ \\
\hline ISK lokalizacija: & \\
Skiltinè paviršinė & $2(2,7)$ \\
Skiltinè gilioji & $28(37,8)$ \\
Pamato branduolių (ganglijų) & $33(44,6)$ \\
Kamieno & $4(5,4)$ \\
Smegenèlių & $7(9,5)$ \\
\hline ISK tūris, ml & $48,76(+-47,95)$ \\
\hline Yra ISK prasiveržimas i i skilvelių sistemą & $47(63,5)$ \\
\hline GKS balai: & \\
SPS & $10,14( \pm 3,99)$ \\
NITS, atvykus & $8,66( \pm 4,32)$ \\
\hline Mirè NITS & $22(29,7)$ \\
\hline
\end{tabular}

Atlikus tiesinę regresiją nustatyta, kad didesnis NLS reikšmingai susijęs su didesniu ISK tūriu $(\mathrm{p}=0,03)$, tuo tarpu kiti pradinio bendro kraujo tyrimo duomenys įtakos ISK tūriui neturejjo. NLS ịtaka ISK tūriui pateikta 2 paveiksle, kiti rodikliai aprašyti 3 lentelèje.

Atlikus tiesinę regresiją nustatyta, kad didesni bendras leukocitų skaičius, neutrofilų skaičius ir ISK tūris siejasi su mažesniu GKS įverčiu NITS. Kiti kintamieji statistiškai reikšmingos įtakos GKS ịverčiams neturejo (4 lentelè).

Atlikus vienfaktorinę logistinès regresijos analizę nustatyta, kad su blogesne pacientų ligos baigtimi yra susiję: didesnis ISK tūris, mažesnis GKS ịvertis, kraujosruvos prasiveržimas ị skilvelių sistemą, didesnis bendras leukocitų skaičius, didesnis neutrofilų ir NLS skaičius $(p<0,05),(5$ lentelè).

2 lentelè. Išgyvenusių ir mirusių nuo ISK pacientų periferinių kraujo ląstelių charakteristikos.

Lasteliu skaičius nurodytas kaip vidurkis su standartiniu nuokrypiu $V( \pm S N)$. NLS neutrofily ir limfocitu santykis. LMS - limfocitu ir monocity santykis.

\begin{tabular}{|l|c|c|c|}
\hline $\begin{array}{l}\text { Periferinio } \\
\text { kraujo ląstelès }\end{array}$ & \multicolumn{2}{|c|}{ Ląstelių skaičius, $\mathbf{n}^{*} \mathbf{1 0}^{\mathbf{9}}$} & \multirow{2}{*}{$\boldsymbol{p}$ reikšmė } \\
\cline { 2 - 3 } išgyvenę & mirę & \\
\hline Leukocitai & $9,21( \pm 3,50)$ & $11,48( \pm 4,61)$ & $\mathbf{0 , 0 2 4}$ \\
\hline Neutrofilai & $6,88( \pm 3,48)$ & $9,19( \pm 4,41)$ & $\mathbf{0 , 0 1 9}$ \\
\hline Limfocitai & $1,65( \pm 0,95)$ & $1,44( \pm 0,87)$ & 0,361 \\
\hline Monocitai & $0,68( \pm 0,34)$ & $0,78( \pm 0,50)$ & 0,41 \\
\hline NLS & $6,30( \pm 5,64)$ & $10,02( \pm 7,47)$ & $\mathbf{0 , 0 4 4}$ \\
\hline LMS & $2,77( \pm 1,76)$ & $2,50( \pm 1,89)$ & 0,559 \\
\hline
\end{tabular}

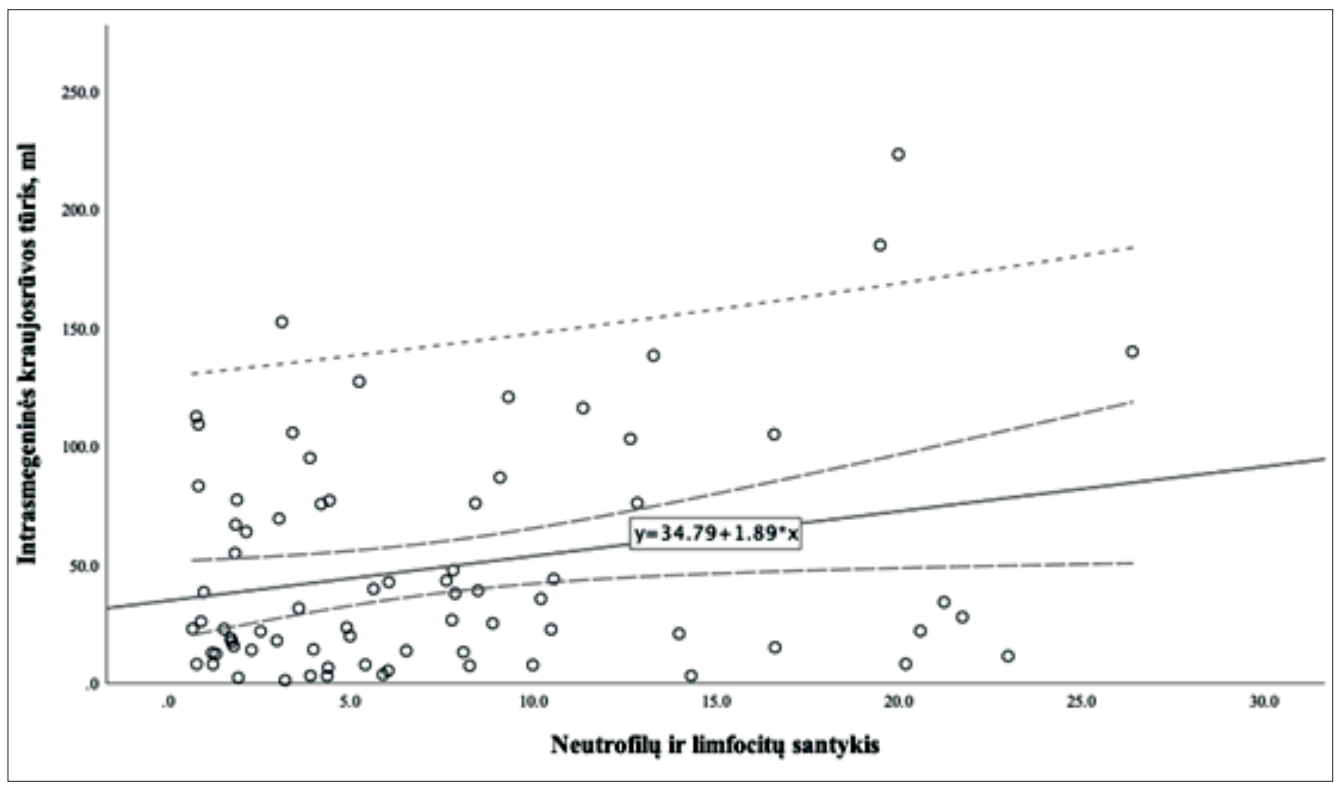

2 pav. Neutrofilų ir limfocitų santykio įtaka intrasmegeninės kraujosruvos tūriui (apskaičiuojamas pagal formulę: ISK tūris $=34,79+1,89 * \mathrm{NLS}$ ) 


\section{Diskusija}

Daugèja įrodymų, kad uždegimas yra svarbus antrinès pažaidos po spontaninès ISK komponentas $[9,10]$. Uždegiminès ląstelès infiltruoja

3 lentelè. Periferiniu kraujo ląsteliu itaka ISK tūriui.

Koeficientai $\beta$ parodo, kiek mililitru padidèja hematomos tūris, kintamajam padidejus vienu vienetu. PI-pasikliautinasis intervalas. Koreguotas $R 2$ atspindi, kokia dali kitimo galima paaiškint konkrečiu kintamuoju. NLS - neutrofilu ir limfocitu santykis. LMS - limfocitu ir monocitu santykis.

\begin{tabular}{|l|c|c|c|c|}
\hline \multirow{2}{*}{ Kintamieji } & \multicolumn{4}{|c|}{ Regresijos charakteristikos } \\
\cline { 2 - 5 } & koeficientas $\beta$ & $p$ & $95 \%$ PI & $\begin{array}{c}\text { koreguotas } \\
\mathrm{R}^{2}\end{array}$ \\
\hline $\begin{array}{l}\text { Bendras leukocitu } \\
\text { skaičius }\end{array}$ & 2,147 & 0,130 & $-0,64-4,94$ & 0,018 \\
\hline Neutrofilu skaičius & 2,239 & 0,121 & $-0,6-5,08$ & 0,020 \\
\hline Limfocitu skaičius & $-2,168$ & 0,723 & $-14,29-9,96$ & $-0,012$ \\
\hline Monocitų skaičius & 2,876 & 0,842 & $-25,7-31,45$ & $-0,013$ \\
\hline NLS & 1,887 & $\mathbf{0 , 0 3 0}$ & $0,19-3,58$ & 0,051 \\
\hline LMS & 0,578 & 0,855 & $-5,71-6,86$ & $-0,013$ \\
\hline
\end{tabular}

4 lentelè. ISK tūrio ir periferinio kraujo ląstelių įtaka GKS įverčiui NITS. Koeficientai $\beta$ parodo, kiek pakinta GKS i vertis, kintamajam padidejus vienu vienetu. PI-pasikliautinasis intervalas. Koreguotas R2 atspindi, kokia dali kitimo galima paaiškinti konkrečiu kintamuoju. GKS - Glasgow komu skalè. ISK - intrasmegeninè kraujosruva. NLS - neutrofilu ir limfocitu santykis. LMS - limfocitu ir monocitu santykis.

\begin{tabular}{|l|l|l|l|l|}
\hline \multirow{2}{*}{ Kintamieji } & \multicolumn{4}{|l|}{ Regresijos charakteristikos } \\
\cline { 2 - 5 } & Koeficientas $\beta$ & $p$ & $95 \%$ PI & Koreguotas R \\
\hline ISK tūris & $-0,035$ & $\mathbf{0 , 0 0 1}$ & $-0,05-(-0,02)$ & 0,141 \\
\hline $\begin{array}{l}\text { Bendras leukocitų } \\
\text { skaičius }\end{array}$ & $-0,298$ & $\mathbf{0 , 0 1 8}$ & $-0,54--0,05$ & 0,062 \\
\hline Neutrofilu skaičius & $-0,308$ & $\mathbf{0 , 0 1 7}$ & $-0,56--0,06$ & 0,064 \\
\hline Limfocitu skaičius & $-0,024$ & 0,966 & $-1,12-1,07$ & $-0,014$ \\
\hline Monocitų skaičius & $-1,190$ & 0,357 & $-3,75-1,37$ & $-0,002$ \\
\hline NLS & $-0,137$ & 0,081 & $-0,29-0,02$ & 0,028 \\
\hline LMS & $-0,021$ & 0,941 & $-0,59-0,55$ & $-0,014$ \\
\hline
\end{tabular}

5 lentelè. Kintamieji ir jų galimybių santykių (GS) vertės, prognozuojant paciento ligos baigti.

PI-pasikliautinasis intervalas. ISK - intrasmegeniné kraujosruva. GKS - Glasgow komu skalè. SPS - skubios pagalbos skyrius. NITS - neurochirurgijos intensyvios terapijos skyrius. IVK - intraventrikuliné kraujosruva. NLS - neutrofily ir limfocitu santykis. LMS - limfocitu ir monocitu santykis.

\begin{tabular}{|l|l|l|l|}
\hline \multirow{2}{*}{ Kintamieji } & \multicolumn{3}{l|}{ Prognostinè verte் } \\
\cline { 2 - 4 } & GS & $95 \%$ PI & p \\
\hline ISK tūris & 1,019 & $1,01-1,03$ & $\mathbf{0 , 0 0 2}$ \\
\hline GKS vertinimas SPS & 0,741 & $0,64-0,86$ & $\mathbf{0 , 0 0 0 1}$ \\
\hline GKS vertinimas NITS & 0,604 & $0,48-0,77$ & $\mathbf{0 , 0 0 0 0 3}$ \\
\hline Prasiveržimas ị skilvelių sistemą & 3,569 & $1,06-12,01$ & $\mathbf{0 , 0 4 0}$ \\
\hline Bendras leukocitų skaičius & 1,156 & $1,01-1,32$ & $\mathbf{0 , 0 3 1}$ \\
\hline Neutrofilų skaičius & 1,167 & $1,02-1,33$ & $\mathbf{0 , 0 2 4}$ \\
\hline Limfocitų skaičius & 0,761 & $0,43-1,36$ & 0,358 \\
\hline Monocitų skaičius & 1,830 & $0,54-6,23$ & 0,334 \\
\hline NLS & 1,091 & $1,01-1,18$ & $\mathbf{0 , 0 2 8}$ \\
\hline LMS & 0,916 & $0,68-1,23$ & 0,554 \\
\hline
\end{tabular}

pažeidimo vietą ir skatina citokinų, chemokinų, laisvujjų radikalų ir kitų potencialiai toksinių medžiagų išlaisvinimą. Uždegiminis atsakas sustiprina spontaninès intrasmegeninès kraujosruvos sukeltą smegenų pažaidą, todèl žalojami audiniai, vystosi hematoencefalinio barjero pakitimai ir masyvi smegenų ląstelių žūtis [9]. Mūsų tyrimas ìvertino, kad mirusių pacientų leukocitų, neutrofilų ir neutrofilų-limfocitų santykio reikšmès buvo statistiškai reikšmingai didesnès. Šiems mūsų rezultatams antrina Y. Kim ir bendraautorių atliktas tyrimas, kuris nustatè, kad neišgyvenusių pacientų tyrimuose buvo stebima didesnè leukocitozè [7]. Pastarajame tyrime nebuvo tirtos atskiros leukocitų populiacijos, tačiau F. Zhang ir bendraautorių atliktas tyrimas jas ịvertino ir nustate, kad statistiškai reikšmingai didesnès pradinès leukocitų, neutrofilų ir neutrofilų-limfocitų santykio reikšmés buvo stebimos neišgyvenusiems pacientams [11]. Apibendrinant kitų autorių ir mūsų gautus rezultatus, galime daryti išvadą, kad leukocitai, neutrofilai ir NLS, dalyvaudami antrinèje pažaidoje, gali sukelti didesnị smegenų sužalojimą, todèl didesnès jų reikšmès būdingos pacientams, kurių ligos baigtis nepalanki.

Didelès apimties pirminè kraujosruva, kraujosruvos lokalizacija ir kraujosruvos tūrio didejjimas yra vieni svarbiausių veiksnių, siejami su prastesne ligos baigtimi. Kraujosruvos tūris dinamikoje padideja apie 30 proc. pacientų, patyrusių ISK. Yra duomenų, kad kraujosruvos tūriui padidèjus 10 proc., mirties tikimybè išauga 5 proc., o tūriui padidèjus vienu mililitru, tikimybè, kad pacientas po gydymo bus visiškai priklausomas, padideja 7 procentais. Literatūroje aprašomi keli galimi kraujosruvos plètimosi mechanizmai, kurie apima besitęsiantį kraujavimą iš vienos plyšusios krujagyslès bei antrini gretimų kraujagyslių suplonejjimą ir plyšimą dèl pirminès kraujosruvos spaudimo [12,13]. Pradinis kraujosruvos tūris ir lokalizacija yra nemodifikuojami rizikos veiksniai, tačiau kraujosruvos tūrio didejimo galima potencialiai išvengti [14]. Esant galimybei sumažinti letalios baigties tikimybę, svarbu atpažinti galimus hematomos tūrio didèjimo rizikos veiksnius. Šiame tyrime nustateme, kad ISK tūrio kitimui reikšmingą ịtaką turèjo neutrofilųlimfocitų santykis. Preklinikinių tyrimų metu pastebèta, kad leukocitai ir jų pagrindiniai komponentai - neutrofilai ir limfocitai dalyvauja uždegiminiame procese, kuris vystosi įvykus spontaninei ISK, taip 
prisidėdami prie antrinès pažaidos ir galimų komplikacijų, ịskaitant kraujosruvos tūrio kitimą $[6,15]$. Y. Sun ir bendraautoriai savo tyrime siekè nustatyti NLS sąsają su kraujosruvos tūriu ir nustatè, kad tyrimuose nustatytas didesnis NLS turèjo įtakos didesniam kraujosruvos tūriui, kas atitinka mūsų gautus rezultatus [16].

Nepaisant tobulëjančio gydymo, dažnai pacientų neurologinè būklè suprastėja per keletą dienų po spontaninès ISK. Vienos priežasties nèra, manoma, kad prastėjančiai neurologinei būklei įtaką gali daryti didelis pradinis kraujosruvos tūris, intrakranijinè hipertenzija dẻl smegenų edemos ar kraujosruvos plètimosi, obstrukcinè hidrocefalija ar antrinis metabolinis pažeidimas [17,18]. Savo tyrimu nustatėme, kad mažesnis tiriamųjų GKS ịvertis buvo susijęs su didesniu ISK tūriu. Literatūros duomenimis, didesnès, difuzinès kraujosruvos, stebimos stacionarizavimo metu, yra susijusios su neurologinès būklès prastèjimu, todèl svarbu nuolat vertinti paciento neurologinę būklę ir imtis tinkamos gydymo taktikos [3,18]. Mūsų tyrimas parodè, kad mažesnis GKS buvo susijęs su didesnèmis leukocitų ir neutrofilų reikšmèmis. Panašius rezultatus nustate R. Behrouz ir bendraautoriai - pacientai, kurių tyrimuose buvo stebima leukocitozé, įvertinti žemesniu GKS įverčiu [19]. Padidèjęs leukocitų ir jų populiacijų skaičius analizuojamas ir preklinikiniuose tyrimuose. N. Khatibi ir kt. eksperimentiniu tyrimu su pelèmis ịrodè, kad sumažinus kraujo neutrofilų kiekị, sumažeja antrinè smegenų pažaida [20]. Šių tyrimų rezultatai ir mūsų radiniai iliustruoja, kad dèl vykstančio uždegimo ir antrinès pažaidos padideję̨s leukocitų ir neutrofilų skaičius bei aktyvumas gali būti siejamas su sunkesne ISK eiga ir prastejančia paciento sąmone [7].

Atliktame tyrime nustatème, kad su prasta pacientų ligos baigtimi reikšmingai susiję yra ISK tūris, GKS ịverčiai, kraujosruvos prasiveržimas ị skilvelių sistemą, taikytas operacinis gydymas, pradinis bendras leukocitų skaičius, neutrofilų skaičius ir NLS. Pastaruoju metu daugeja tyrimų, kuriuose daugiausiai dèmesio sulaukia ne bendras leukocitų skaičius, bet būtent neutrofilų skaičius ir jų santykis su limfocitais. NLS yra patikimas sudettinis žymuo, atspindintis specifinį ir nespecifinį imuninị atsaką, tad tyrimuose jis gali iliustruoti ūminį uždegimą po ISK. Visuose tyrimuose nustatoma, kad neutrofilai ir NLS prognozuoja ligos baigti, neurologinị deficitą ar net padidina jau naudojamų skalių prognostinę vertę [21-25]. Mūsų tyrimu taip pat pabrèžiama būtent neutrofilų ir jų santykio su limfocitais, kaip geriausio imuninio atsako žymens ISK atveju, sąsaja su blogesne ligos baigtimi. NLS ir jo koreliacija su spontaninès intrasmegeninès kraujosruvos gydymo baigtimi analizuojama F. Wang ir bendraautoriu atliktame tyrime. Jis parode, kad neišgyvenusių pacientų NLS buvo didesnis ir galèjo būti naudojamas kaip predik- cinis veiksnys 30 dienų mirštamumui po spontaninès ISK nustatyti, kas atitinka mūsų gautus rezultatus [26]. Atkreipiant dèmesị ị šiuo metu esamas ribotas terapines galimybes, didejjantis skaičius tyrimų, pabrèžiančių imuninio atsako vaidmenį, teikia vilčiu ateityje sulaukti efektyvaus imunomoduliacinio gydymo [27].

\section{Išvados}

1. Didesnis pradinis bendras leukocitų skaičius periferiniame kraujyje susijęs su mažesniu Glasgow komų skalès ivvertinimu ir didesne mirties tikimybe, patyrus spontaninę intrasmegeninę kraujosruvą.

2. Didesnis absoliutus neutrofilų skaičius susijęs su mažesniu Glasgow komų skalès įvertinimu, tuo tarpu didesnis neutrofilu ir limfocitų santykis siejasi su didesniu intrasmegeninès kraujosruvos tūriu. Didesnis neutrofilų skaičius bei neurofilų ir limfocitų santykis nepriklausomai siejasi su didesne mirties tikimybe.

\section{Literatūra}

1. Garg R, Biller J. Recent advances in spontaneous intracerebral hemorrhage. F1000Research 2019;8.

https://doi.org/10.12688/f1000research.16357.1

2. Balami JS, Buchan AM. Complications of intracerebral haemorrhage. Lancet Neurol 2012;11(1)101-18.

https://doi.org/10.1016/S1474-4422(11)70264-2

3. de Oliveira Manoel AL, Goffi A, Zampieri FG, Turkel-Parrella D, Duggal A, Marotta TR, et al. The critical care management of spontaneous intracranial hemorrhage: a contemporary review. Critical Care 2016;20(1).

https://doi.org/10.1186/s13054-016-1432-0

4. Zheng H, Chen C, Zhang J, Hu Z. Mechanism and therapy of brain edema after intracerebral hemorrhage. Cerebrovascular Diseases 2016;42(3-4):155-69.

https://doi.org/10.1159/000445170

5. Adeoye O, Walsh K, Woo JG, Haverbusch M, Bsn RN, Moomaw $\mathrm{CJ}$, et al. Peripheral monocyte count is associated with casefatality after intracerebral hemorrhage. 2013; https://doi.org/10.1016/j.jstrokecerebrovasdis.2013.09.006

6. Wang J. Preclinical and clinical research on inflammation after intracerebral hemorrhage. Progress in Neurobiology. 2010;92:463-77.

https://doi.org/10.1016/j.pneurobio.2010.08.001

7. Kim Y, Han MH, Kim CH, Kim JM, Cheong JH, Ryu J il. Increased short-term mortality in patients with spontaneous intracerebral hemorrhage and its association with admission glucose levels and leukocytosis. World Neurosurgery 2017;98:503-11. https://doi.org/10.1016/j.wneu.2016.11.087

8. Kothari RU, Brott T, Broderick JP, Barsan WG, Sauerbeck LR, Zuccarello M, et al. The ABCs of measuring intracerebral 
hemorrhage volumes. 1996;27(8):1304-5.

https://doi.org/10.1161/01.STR.27.8.1304

9. Zhou Y, Wang Y, Wang J, Anne Stetler R, Yang Q-W. Inflammation in intracerebral hemorrhage: from mechanisms to clinical translation. Progress in Neurobiology. 2014;115.

https://doi.org/10.1016/j.pneurobio.2013.11.003

10. Keep RF, Hua Y, Xi G. Intracerebral haemorrhage: mechanisms of injury and therapeutic targets. The Lancet Neurology 2012;11:720-31.

https://doi.org/10.1016/S1474-4422(12)70104-7

11. Zhang F, Ren Y, Fu W, Wang Y, Qian J, Tao C, et al. Association between neutrophil to lymphocyte ratio and blood glucose level at admission in patients with spontaneous intracerebral hemorrhage. Scientific Reports 2019;9(1).

https://doi.org/10.1038/s41598-019-52214-5

12. Schlunk F, Greenberg SM. The pathophysiology of intracerebral hemorrhage formation and expansion. Translational Stroke Research 2015;6(4).

https://doi.org/10.1007/s12975-015-0410-1

13. Brouwers HB, Greenberg SM. Hematoma expansion following acute intracerebral hemorrhage. Cerebrovascular Diseases 2013;35(3).

https://doi.org/10.1159/000346599

14. Brouwers HB, Chang Y, Falcone GJ, Cai X, Ayres AM, Battey TWK, et al. Predicting hematoma expansion after primary intracerebral hemorrhage. JAMA Neurology 2014;71(2).

https://doi.org/10.1001/jamaneurol.2013.5433

15. Lattanzi S, Cagnetti C, Provinciali L, Silvestrini M. Neutrophilto-lymphocyte ratio predicts the outcome of acute intracerebral hemorrhage. Stroke 2016;47(6).

https://doi.org/10.1161/STROKEAHA.116.013627

16. Sun Y, You S, Zhong C, Huang Z, Hu L, Zhang X, et al. Neutrophil to lymphocyte ratio and the hematoma volume and stroke severity in acute intracerebral hemorrhage patients. The American Journal of Emergency Medicine 2017;35(3).

https://doi.org/10.1016/j.ajem.2016.11.037

17. Sun W, Peacock A, Becker J, Phillips-Bute B, Laskowitz DT, James ML. Correlation of leukocytosis with early neurological deterioration following supratentorial intracerebral hemorrhage. Journal of Clinical Neuroscience 2012;19(8).

https://doi.org/10.1016/j.jocn.2011.11.020

18. Specogna A v., Turin TC, Patten SB, Hill MD. Factors associated with early deterioration after spontaneous intracerebral hemorrhage: a systematic review and meta-analysis. PLoS ONE 2014;9(5).

https://doi.org/10.1371/journal.pone.0096743

19. Behrouz R, Hafeez S, Miller CM. Admission leukocytosis in intracerebral hemorrhage: associated factors and prognostic implications. Neurocritical Care 2015;23(3).

https://doi.org/10.1007/s12028-015-0128-7
20. Khatibi NH, Lee LK, Zhou Y, Chen W, Rolland W, Fathali N, et al. Neutrophil depletion diminishes monocyte infiltration and improves functional outcome after experimental intracerebral hemorrhage. Acta Neurochirurgica 2011;111(September 2007):1-7.

21. Lattanzi S, Cagnetti C, Rinaldi C, Angelocola S, Provinciali L, Silvestrini M. Neutrophil-to-lymphocyte ratio improves outcome prediction of acute intracerebral hemorrhage. Journal of the Neurological Sciences 2018;387(September 2017):98-102. https://doi.org/10.1016/j.jns.2018.01.038

22. Lattanzi S, Cagnetti C, Provinciali L, Silvestrini M. Neutrophilto-lymphocyte ratio and neurological deterioration following acute cerebral hemorrhage. Oncotarget. 2017;8(34):57489-94. https://doi.org/10.18632/oncotarget.15423

23. Lattanzi S, Brigo F, Trinka E, Cagnetti C, di Napoli M, Silvestrini M. Neutrophil-to-lymphocyte ratio in acute cerebral hemorrhage: a system review. Translational Stroke Research 2019; 10(2):137-45.

https://doi.org/10.1007/s12975-018-0649-4

24. Wang F, Hu S, Ding Y, Ju X, Wang L, Lu Q, et al. Neutrophilto-lymphocyte ratio and 30-day mortality in patients with acute intracerebral hemorrhage. Journal of Stroke and Cerebrovascular Diseases 2016;25(1):182-7.

https://doi.org/10.1016/j.jstrokecerebrovasdis.2015.09.013

25. Zhang F, Ren Y, Shi Y, Fu W, Tao C, Li X, et al. Predictive ability of admission neutrophil to lymphocyte ratio on short-term outcome in patients with spontaneous cerebellar hemorrhage. Medicine 2019;98(25):e16120.

https://doi.org/10.1097/MD.0000000000016120

26. Wang F, Hu S, Ding Y, Ju X, Wang L, Lu Q, et al. Neutrophilto-lymphocyte ratio and 30-day mortality in patients with acute intracerebral hemorrhage. Journal of Stroke and Cerebrovascular Diseases. 2016;25(1).

https://doi.org/10.1016/j.jstrokecerebrovasdis.2015.09.013

27. Shao A, Zhu Z, Li L, Zhang S, Zhang J. Emerging therapeutic targets associated with the immune system in patients with intracerebral haemorrhage (ICH): from mechanisms to translation. EBioMedicine 2019;45(253):615-23.

https://doi.org/10.1016/j.ebiom.2019.06.012

\section{PERIPHERAL BLOOD LEUKOCYTES INFLUENCE TO OUTCOMES OF SPONTANEOUS INTRACEREBRAL HEMORRHAGE}

B. Kakta, L. Grygalytė, T. Tamošuitis, N. Balčiūnienė

Keywords: intracerebral hemorrhage, peripheral lymphocyte count, neutrophil count, neutrophil-to-lymphocyte ratio.

Summary

Introduction. Spontaneous intracerebral hemorrhage (ICH) is associated with high mortality and few treatment options. The aim of this study is to evaluate peripheral lymphocyte and its populations' effects on outcomes of patients treated in neurosurgery intensive care unit after spontaneous ICH. 
Methods. We performed a single center retrospective study of 114 patients' case records that were treated in Hospital of Lithuanian university of health sciences Kaunas clinics neurosurgery intensive care unit after spontaneous ICH from December 2018 to December 2019. The data from 74 patients who met the inclusion criteria were used for further analysis. Demographic and clinical variables, such as Glasgow coma scale (GCS), ICH volume and characteristics, peripheral blood leukocyte, neutrophil, lymphocyte and monocyte counts were analyzed to determine possible connections to ICH outcome.

Results. Leukocyte, neutrophil counts and neutrophil-to-lymphocyte ratios (NLR) were lower in survived patients $(p<0,05)$. Linear regression analysis revealed that higher NLR is associated with greater ICH volume $\left(\beta=1,887\right.$, adj. $\left.R^{2}=0,051, p=0,03\right)$, therefore higher leukocyte count $\left(\beta=-0,298\right.$, adj. $\left.R^{2}=0,062, p=0,018\right)$ and higher neutrophil count $\left(\beta=-0,308\right.$, adj. $\left.R^{2}=0,064, p=0,017\right)$ are associated with lower GCS score. Binary logistic regression analysis revealed that leukocyte count $(\mathrm{OR}=1,156, \mathrm{p}=0,031)$, neutrophil count $(\mathrm{OR}=1,167, \mathrm{p}=0,024)$ and $\mathrm{NLR}(\mathrm{OR}=1,091, \mathrm{p}=0,028)$ are independently associated with higher death as an outcome probability.

Conclusion. Higher peripheral leukocyte count and neutrophil count are both independently associated with lower GCS score and higher death probability after spontaneous ICH. Higher NLR is associated with greater hematoma volume and death probability after spontaneous ICH.

Correspondence to: balciunieneneringa@gmail.com

Gauta 2021-04-18

\section{KVIEČIAME PRENUMERUOTI „SVEIKATOS MOKSLŲ“ŽURNALĄ 2021 METAIS!}

Žurnalas „Sveikatos mokslai“ (Index Copernicus, EBSCO host (Academic Search Complete), Gale (Academic OneFile), ProQuest (Ulrich's, Summon), Australia (ERA) 2012 Journal List (ERA ID 34962) skirtas visų specialybių gydytojams, slaugytojams ir kitiems specialistams, spausdina mokslinius straipsnius lietuvių, anglų kalbomis. Reikalavimai straipsniams atitinka mokslo leidiniams keliamus reikalavimus. Žurnalas spaudos kioskuose neparduodamas. Žurnalą, kuris leidžiamas kartą per du mẻnesius, galima užsiprenumeruoti visuose Lietuvos pašto skyriuose ir internetu: www.prenumeruok.It Prenumeratos kaina nesikeičia: visiems metams - 36 EUR, šešiems mėnesiams - 18 EUR, keturiems mẻnesiams - 12 EUR, dviem mėnesiams - 6 EUR. Prenumeratos kodas: 5348. Žurnalo autoriams straipsnių spausdinimas ir jų internetinè sklaida mokama. 